\title{
ANTIOXIDANT PROPERTY OF ANTIHYPERTENSIVE DRUGS (CARVEDILOL, ENALAPRIL, AND AMLODIPINE) ON LIVER FUNCTION IN ANIMAL (RATS) MODELS
}

\author{
PUSULOORI RAJESH* \\ Department of Pharmacology, Kurnool Medical College, Kurnool, Andhra Pradesh, India. Email: drpusuloorirajesh@yahoo.co.in
}

Received: 05 July 2016, Revised and Accepted: 14 July 2016

\section{ABSTRACT}

Objective: The antihypertensive drugs (beta-blockers - carvedilol, calcium channel blocker - amlodipine, and angiotensin-converting enzyme inhibitor - enalapril) were investigated for its hepatoprotective effect by antioxidant property against carbon tetrachloride ( $\mathrm{CCl}_{4}$ )-induced acute liver damage on albino rats.

Methods: In this study the liver was damaged by giving Carbon tetra chloride $\left(\mathrm{CCl}_{4}\right)-1 \mathrm{ml} / \mathrm{kg}$-p.o. $\mathrm{After}$ giving $\mathrm{CCl}{ }_{4}(1 \mathrm{ml} / \mathrm{kg})$, it significantly elevated the serum levels of biochemical markers such as serum glutamate-pyruvate transaminase, serum glutamic oxaloacetic transaminase, alkaline phosphatase, total bilirubin, protein, and depleted antioxidant enzymes glutathione. After treatment with carvedilol (10 mg/kg), enalapril (0.5 mg/kg), and amlodipine $(10 \mathrm{mg} / \mathrm{kg}$ ) for 2 weeks, these drugs were significantly reduces the elevated levels of biochemical markers mentioned above.

Conclusion: These results suggest that these antihypertensive drugs may have the potential therapeutic value in the treatment of CCl ${ }_{4}$-induced hepatic damage and some liver diseases. Hepatoprotective activity of these drugs may be attributed to the antioxidant principles in it.

Keywords: Antioxidant, Carvedilol, Enalapril, Amlodipine, Carbon tetrachloride, Hepatoprotective.

(C) 2016 The Authors. Published by Innovare Academic Sciences Pvt Ltd. This is an open access article under the CC BY license (http://creativecommons org/licenses/by/4. 0/) DOI: http://dx.doi.org/10.22159/ajpcr.2016.v9s2.13924

\section{INTRODUCTION}

In the treatment of hypertension, many drugs such as beta-blockers, angiotensin-converting enzyme inhibitors, and calcium channel blockers are commonly used. Sometimes, combination of these drugs more effective than individual drugs [1]. These drugs also contain antioxidant compounds which protect the cells against the damaging effects of reactive oxygen species (ROS). ROS such as superoxide anion, hydroxyl radical, and hydrogen peroxide play a crucial role in the development of various ailments such as arthritis, asthma, dementia, mongolism, carcinoma, and Parkinson's disease [2]. The free radicals in the human body are generated through aerobic respiration or from exogenous sources [3]. Some of the in vivo free radicals play a positive role in phagocytosis, energy production, and regulation of cell growth. However, free radicals may also be damaging. Free radicals produced in the body react with various biological molecules namely lipids, proteins, and deoxyribonucleic acids resulting in the imbalance between oxidants and antioxidants. Even though our body is safeguarded by natural antioxidant defense, there is always a demand for antioxidants from secondary sources. According to literature available, these antihypertensives are also having antioxidant property [4,5]. In the present study, the antihypertensives were selected to evaluate its antioxidant potential on laboratory animal model.

\section{METHODS}

Before conducting this study, the Institutional Animal Ethical Committee permission was taken. This study was conducted strictly according to the CPCSEA guidelines.

\section{Experimental design}

The animals used for the experiment were divided into five groups and six rats for each group. Food was withdrawn $12 \mathrm{hr}$ before carbon tetrachloride $\left(\mathrm{CCl}_{4}\right)$ administration to enhance the acute liver toxicity in all test groups of animal models [6].

\section{Grouping of rats}

Group: I (control): Treated with 2\% gum acacia - $2 \mathrm{ml} / 100 \mathrm{~g}$

Group: II (standard): Treated with silymarin $(100 \mathrm{mg} / \mathrm{kg})$
Group: III (T-1): Treated with carvedilol (10 mg/kg/day, orally) Groups: IV (T-2): Treated with enalapril $(0.5 \mathrm{mg} / \mathrm{kg} /$ day, orally) Group: V (T-3): Treated with amlodipine (10 mg/kg/day, orally).

All the groups were treated with test drugs orally $1 \mathrm{hr}$ before $\mathrm{CCl}_{4}$ administration. After $1 \mathrm{hr}$ of giving test drugs to all groups of animal, hepatic injury was induced by intraperitoneal injection of $1: 1 \mathrm{v} / \mathrm{v} \mathrm{CCl}$ in olive oil $(1 \mathrm{ml} / \mathrm{kg})$ daily for 14 days. On the $15^{\text {th }}$ day, all the animals were anesthetized, and blood was collected from the carotid artery at the neck for the determination of enzyme levels in serum, and then, all animals were sacrificed [7].

\section{RESULTS}

All the groups (I-V) of animals were treated with three test drugs - carvedilol (10 mg/kg), enalapril $(0.5 \mathrm{mg} / \mathrm{kg})$, and amlodipine (10 mg/kg) for test groups, $2 \%$ gum acacia - $2 \mathrm{ml} / 100 \mathrm{~g}$ for control group and silymarin (100 mg/kg) for standard group, $1 \mathrm{hr}$ before giving $\mathrm{CCl}_{4}(1 \mathrm{ml} / \mathrm{kg})$. The carvedilol- and silymarin-treated animals were shown a significant reduction in serum marker enzymes $(\mathrm{p}<0.001)$. Carvedilol $(10 \mathrm{mg} / \mathrm{kg})$ and silymarin $(100 \mathrm{mg} / \mathrm{kg})$ greatly reduce enzyme levels, but enalapril $(0.5 \mathrm{mg} / \mathrm{kg})$ and amlodipine $(10 \mathrm{mg} / \mathrm{kg})$ have shown less effect than carvedilol and silymarin but have shown better effect than $\mathrm{CCl}_{4}$-induced hepatotoxicity in control group rats [8]. Liver weight almost comes to normal.

\section{Statistical analysis}

The results obtained were expressed as mean \pm standard error of the mean and were analyzed by the application of one-way analysis of variance, and $\mathrm{p}<0.05$ was considered significant.

All the results were depicted in Table 1.

Histological examination of the hepatic tissue in $\mathrm{CCl}_{4}$-treated rats shown that $\mathrm{CCl}_{4}$ had produced profound inflammation and congestion particularly in sinusoids. Pre-treatment of animals with silymarin (100 mg/kg) in Group-II and carvedilol, Enalapril, and amlodipine in Group-III, IV, V respectively have not shown any pathological change in histological study. 
Table 1: Effect of antihypertensive drugs on liver function ( $n=6$, Mean \pm SEM)

\begin{tabular}{llllll}
\hline Groups (I-V) & SGOT (IU/ml) & SGPT (IU/ml) & ALP (IU/ml) & Total bilirubin (Mg/d) & Liver weight (g/100 g bw) \\
\hline Control (CCl $-1 \mathrm{ml} / \mathrm{kg})$ & $259.8 \pm 0.60$ & $255.63 \pm 1.21$ & $222.2 \pm 0.36$ & $2.05 \pm 0.03$ & $3.71 \pm 0.03$ \\
Standard (silymarin-100 mg/kg) & $161.2 \pm 0.21^{* * *}$ & $149.35 \pm 0.15^{* * *}$ & $169.4 \pm 0.31^{* * *}$ & $0.79 \pm 0.05^{* * *}$ & $2.56 \pm 0.01^{* * *}$ \\
Test-1 (carvedilol-10 mg/kg) & $177.7 \pm 0.10^{* *}$ & $182.45 \pm 1.15^{* *}$ & $173.8 \pm 0.13^{* *}$ & $1.11 \pm 2.21^{* * *}$ & $3.10 \pm 0.01^{* *}$ \\
Test-2 (enalapril-0.5 mg/kg) & $192.4 \pm 0.09^{*}$ & $200.65 \pm 2.33^{*}$ & $211.5 \pm 0.14^{*}$ & $1.86 \pm 0.03^{* *}$ & $3.73 \pm 0.50^{*}$ \\
Test-3 (amlodipine-10 mg/kg) & $201.2 \pm 0.22^{*}$ & $223.42 \pm 5.31^{*}$ & $201.9 \pm 0.17$ & $2.20 \pm 3.31^{*}$ & $3.51 \pm 0.02^{*}$ \\
\hline
\end{tabular}

${ }^{*} \mathrm{p}<0.05,{ }^{* *} \mathrm{p}<0.01,{ }^{* * *} \mathrm{p}<0.001$ compared to control. SGOT: Serum glutamic oxaloacetic transaminase, SGPT: Serum glutamate-pyruvate transaminase, ALP: Alkaline phosphatase, $\mathrm{CCL}_{4}$ : Carbon tetrachloride

\section{DISCUSSION}

In the present study, these antihypertensive drugs (carvedilol, enalapril, and amlodipine) were selected to prove its antioxidant effect by hepatoprotective activity scientifically using experimental animal models. Selection of these drugs for this study is due to its cardioprotective activity, vascular protective activity by reducing vascular stress in the treatment of hypertension. Stress-reducing property of these drugs may be due to antioxidant activity on the blood vessels, renal system, and cardiac muscle [9]. $\mathrm{CCl}_{4}$-induced hepatic damage in rats model was used for the study. $\mathrm{CCl}_{4}$ is commonly used drug to induce hepatotoxicity by generating free radicals in the experimental study [10]. Liver damage was confirmed by high serum enzymes (serum glutamic oxaloacetic transaminase, serum glutamate-pyruvate transaminase, alkaline phosphatase, and tuberculosis) levels because they are cytoplasmic in location and released into circulation after hepatocyte damage. Liver weight also increased due to toxic effect of $\mathrm{CCl}_{4}$. Due to antioxidant property of these antihypertensive drugs inhibit the generation of free radicals in hepatotoxicity induced by $\mathrm{CCl}_{4}$ in rats

The carvedilol- and silymarin-treated animals were shown a significant reduction in serum marker enzymes $(p<0.001)$. Carvedilol $(10 \mathrm{mg} / \mathrm{kg})$ and silymarin $(100 \mathrm{mg} / \mathrm{kg})$ greatly reduce enzyme levels, but enalapril $(0.5 \mathrm{mg} /$ $\mathrm{kg}$ ) and amlodipine $(10 \mathrm{mg} / \mathrm{kg}$ ) have shown less effect than carvedilol and silymarin but have shown better effect than $\mathrm{CCl}_{4}$-induced hepatotoxicity in the control group rats. Liver weight almost comes to normal [11,12].

Its probable mechanism in hepatic damage was antioxidant effect by preventing free radical releasing. In histological examination also, no inflammatory cells and very less necrotic cells were appeared with carvedilol (Group-III) treated $(10 \mathrm{mg} / \mathrm{kg}$ ) and silymarin (Group-II)treated groups. Few inflammatory cells were appeared in enalapriltreated $(0.5 \mathrm{mg} / \mathrm{kg})$ and amlodipine-treated groups $(10 \mathrm{mg} / \mathrm{kg})$. Serum enzymes levels were also comes to normal. The weight of the liver also in both the models was effectively reduced in carvedilol- and silymarintreated groups when compared with the control group.

\section{CONCLUSION}

The present study indicates that the antihypertensive drugs (carvedilol, enalapril, and amlodipine) have potential hepatoprotective activity by its antioxidant property. Hence, these drugs can be used as antioxidants in various conditions. However, it needs further clinical trials before complete trust and usage.

\section{ACKNOWLEDGMENT}

The author Dr. P. Rajesh expresses extreme pleasure and thanks to staffs and technicians of Kurnool Medical College, who supported and helped throughout this research work.

\section{REFERENCES}

1. Halliwell B, Gutteridge JM. Role of free radicals and catalytic metal ions in human disease: An overview. Methods Enzymol 1990;186:1-85.

2. Rimbach G, Fuchs J, Packer L. Application of nutrigenomics tools to analyze the role of oxidants and antioxidants in gene expression. In: Rimbach G, Fuchs J, Packer L, editors. Nutrigenomics. FL, USA: Taylor and Francis Boca Raton Publishers; 2005. p. 1-12.

3. Kähkönen MP, Hopia AI, Vuorela HJ, Rauha JP, Pihlaja K, Kujala TS, et al. Antioxidant activity of plant extracts containing phenolic compounds. J Agric Food Chem 1999;47:3954-62.

4. Vaidyaratnam PS. Varier's Indian Medicinal Plants (Compendium of 500 Species). Vol. 5. Hyderabad: Orient Longman; 1997.

5. Semiz A. Antioxidant effect of beta blockers in preclinical studies. Afr J Biotechnol 2007;6(3):273-7.

6. Health Effects Test Guidelines, Acute Oral Toxicity (Computer Program). OPPTS 870, 1100 United States Office of prevention, Pesticides and Toxic Substances Environmental Protection Agency. (7101). Available from: http://www.epa.gov/opptsfrs/home/guideline. htm. 5/6/2004.

7. Sahu N, Das S. Hepatoprotective activity of Eugenia jumbose Linn. On albino rats. IJP 2006;5:22-6.

8. Galighor AE, Kozloff EN. Essentials of Practical Micro Technique. $2^{\text {nd }}$ ed. New York: Lea and Fibiger; 1976.

9. Jitendra J, Vineeta T, Ashok K, Brijesh K, Singh P. Rosa centifolia: Plant review. Int J Res Pharm Chem 2012;2(3):794-6.

10. Shenoy KA, Somayaji SN, Bairy KL. Hepatoprotective effect of Ginkgo biloba in carbon tetrachloride induced hepatic injury in rats. IJP 2001;33:260-6.

11. Claret SB. Carvedilol effect on serum enzymes. Med J Can 1998;9(4):38-41.

12. Sallie R, Tredger JM, William R. Drugs and the liver. Part-1: Testing liver functions. Biopharm Drug Dispos 1991;12(4):251-9. 